\title{
FACTORS OF DESTINATION QUALITY FROM THE POINT OF VIEW OF SERVICE PROVIDERS
}

\author{
[Faktory kvality destinace z pohledu poskytovatelů služeb] \\ Š́rka Stojarová ${ }^{1}$, Kateřina Ryglová ${ }^{2}$, Ida Rašovská ${ }^{3}$, Andrea Králíková ${ }^{4}$ \\ ${ }^{1}$ Mendelova univerzita v Brně, Provozně ekonomická fakulta, Zemédělská 5,613 00 Brno \\ Email:sarka@mendelu.cz. \\ ${ }^{2}$ Mendelova univerzita v Brně, Provozně ekonomická fakulta, Zemédělská 5,613 00 Brno \\ Email: katerina.ryglova@mendelu.cz. \\ ${ }^{3}$ Mendelova univerzita v Brně, Provozně ekonomická fakulta, Zemědělská 5,613 00 Brno \\ Email: ida.rasovska@mendelu.cz \\ ${ }^{4}$ Mendelova univerzita v Brně, Provozně ekonomická fakulta, Zemédělská 5,613 00 Brno \\ Email:xkraliko@node.mendelu.cz
}

\begin{abstract}
The article is focused on the issue of the perception of the destination quality. Primary research has been concerned with the evaluation of individual quality factors by service providers distributed by sectors in tourism industry. According to the service providers, the most significant factors of destination quality are the sense of security, the quality of staff in tourism services, and natural attractions. On the other hand, the least important factor for the service providers was local transportation followed by additional infrastructure. Factors were rated depending on the type of service provider, the overall quality of the destination, and the destination management activity in the destination. The dependence of the assessment of the destination quality factors on the type of provider was demonstrated in 13 factors, the overall quality assessment of the destination for 10 factors and the destination management activities in the given destination for 6 factors out of a total of 19 factors examined. It is also pointed to differences in perceptions between service providers and visitors. The authors also refer to the dependence of the significance of the destination quality factors on the predominant form of tourism. The recommendations for providers and organizations of destination management are suggested.
\end{abstract}

Keywords: destination, destination quality factors, gap analysis, service provider's perception, service quality, tourism, visitor's perception.

JEL classification: L83, L84, Z30, Z31, Z32

Doručeno redakci: 10.7.2017; Recenzováno: 21.7.2017; 31.7.2017; Schváleno k publikování: 20.9.2017

\section{Úvod}

I když cestovní ruch představuje neustále rostoucí odvětví, požadavky na kvalitu služeb se ze strany zákazníka neustále zvyšují. Poskytovatelé služeb v cestovním ruchu jsou vystaveni stále intenzivnějšímu konkurenčnímu prostředí. Na základě dat z Českého statistického úřadu (2017) v České republice v roce 2015 tvořil cestovní ruch 2,8 procenta hrubého domácího produktu. Meziročně došlo k 5,3 procentnímu nárůstu, nebot' výdaje turistů na cestovní ruch činily v tomto roce 250 miliard Kč. Zahraniční návštěvníci se na celkových výdajích podíleli téměř 60 procenty, kdežto tuzemští návštěvníci utratili prostřednictvím domácího cestovního ruchu 102 miliard Kč, tedy více jak 40 procent. Podíl cestovního ruchu na celkové zaměstnanosti činil 4,4 procenta, což představuje 228 tisíc pracujících v tomto odvětví. Při porovnání struktury celkových výdajů se přibližně jedná o 20 procent výdajů na dopravu, 20 procent výdajů na stravování a necelých 20 procent za ubytovací služby, téměř 30 procent pak činily výdaje za zboží. Rostoucí trend trval i v roce 2016, meziročně se zvýšil o 6,9 procenta počet hostů ubytovaných $\mathrm{v}$ hotelích a dalších ubytovacích zařízeních, kdy jejich 
počet přesáhl 18,37 milionu. I když jsou tato data pro poskytovatele služeb pozitivní zprávou, jsou také podnětem pro vstup nové konkurence, a tedy je nutné se zabývat vnímanou kvalitou služeb nabízených v destinaci, jak ze strany zákazníků, tak i ze strany poskytovatelů služeb. Cílem tohoto článku je posoudit významnost faktorů kvality destinace z hlediska poskytovatele a porovnat je s hodnotami uvedenými návštěvníky destinace, dále prozkoumat možné rozdíly ve vnímání kvality destinace poskytovateli různých služeb cestovního ruchu, zjistit závislost hodnocení jednotlivých faktorů na typu poskytovatele, na celkovém hodnocení kvality destinace a na aktivitě organizace destinačního managementu $v$ dané destinaci. Výzkumnou otázkou je také zjištění závislosti významnosti faktorů kvality destinace na převažující formě cestovního ruchu. Tyto výsledky mohou přispět k hlubšímu porozumění hodnocení kvality destinace jak ze strany zákazníků, tak ze strany poskytovatelů různých služeb cestovního ruchu v odlišných typech destinace.

\section{Metodologie}

Zkoumané faktory definující kvalitu destinace byly určeny na základě vlastního kvalitativního výzkumu a také dřívějších kvantitativních šetření. Pro stanovení způsobu měření byly zohledněny nejčastěji používané modely jako SERVQUAL, GAP, Kano a EFQM. Na základě prací zabývajících se kvalitou destinace, kde mezi nejvýznamnější patří Buhalis (2011) Middleton a kol. (2009), Woods a Deegan (2003) a Grönroos, (2007), bylo vymezeno devatenáct faktorů kvality destinace z pohledu cestovního ruchu. Vnímání významu jednotlivých faktorů ze strany návštěvníků destinace proběhlo v květnu až srpnu 2015 a zúčastnilo se jej 1097 respondentů. Pro jejich výběr byly primárně použity základní demografické kvóty jako pohlaví, věk, vzdělání a bydliště; kvóty dané zveřejněnými populačními charakteristikami Českého statistického úřadu za rok 2014, viz Ryglová a kol. (2015). Jako nejvýznamnější faktory určili návštěvníci faktor pocitu bezpečí a faktor čistoty destinace, konkrétní hodnoty z tohoto výzkumu jsou uvedeny v Obr. 2 v Kapitole 3., podrobnější výsledky pak uvádí Stojarová a kol. (2016).

Dotazníkové šetření na vnímání významů faktorů kvality destinace na straně nabídky se stejným zaměřením proběhlo $\mathrm{v}$ říjnu až prosinci 2016 a respondenti byli vybráni z charakteristických odvětví cestovního ruchu opět s ohledem na zveřejněné statistické údaje Českého statistického úřadu, Poništová (2017), kde na základě počtu zaměstnaných osob v jednotlivých odvětvích cestovního ruchu byli dotazování poskytovatelé v kategoriích Hotely a podobná zařízení $11 \%$, Restaurace a podobná zařízení $41 \%$, Osobní doprava, pronájem zařízení a doplňkové služby pro osobní přepravu 27\%, Cestovní agentury a podobná zařízení $3 \%$, Kulturní služby $10 \%$ a v kategorii Sportovní a rekreační služby $8 \%$ respondentů. Dotazníkové šetření probíhalo papírovou a elektronickou formou a zúčastnilo se jej 343 respondentů. Respondenti ve vztahu k významu faktorům měli možnost na škále přidělit 1 až 5 bodů, kde 1 představovala velmi nízkou významnost a 5 velmi vysokou významnost faktoru kvality destinace. V př́spěvku jsou posouzeny střední hodnoty u různých typů poskytovatelů. Pro testování závislosti významu faktorů byl použit Pearsonův chí-kvadrát test V kontingenční tabulce, závislost na typu poskytovatele byla zkoumána na $5 \%$ hladině významnosti. Pro zjištění závislosti významnosti faktorů kvality destinace na převládající formě cestovního ruchu $\mathrm{v}$ destinaci byl použit Mann-Whitneyův U test nebo-li MannWhitneyo̊v-Wilcoxonův test, nastavený na $5 \%$ hladině významnosti. Pro porovnání s vnímáním kvality destinace zákazníků bylo použito výše uvedené šetření Ryglová a kol. (2015). 


\section{Literární východiska}

Pojem kvality není snadno definovatelný a ani v literatuře nenajdeme jednoznačnou definici vztahující se ke kvalitě služeb cestovního ruchu či ke kvalitě destinace. Gummesson (1993) rozlišuje dvě možná pojetí kvality, první převažující ve výrobním sektoru, kdy kvalita je definována shodou produktu s požadavky a specifikacemi firmy s důrazem na standardizaci. Druhé pojetí kvality je dáno primárně užitkem a spokojeností zákazníka. Obdobně se staví k problematice Grönroose (2007), který definuje dvě základní podoby kvality. První představuje technická kvalita, která se vztahuje k prvkům, které lze změřit, hodnocení je obecně snazší, ale $\mathrm{v}$ mnoha př́ípadech ji může posoudit pouze odborník a také posouzení může vyžadovat delší časovou prodlevu od okamžiku konečného výstupu. Naproti tomu funkční kvalitu nelze rychle určit změřením, nedá se objektivně posoudit, působí zde vícero vnějších vlivů, hodnocení je komplexnějšího charakteru. Na rozdíl od výrobního sektoru tedy je pojem kvality ve službách podstatně hưře uchopitelný, subjektivní vnímání je více určující neb je celkový proces více provázán $\mathrm{s}$ lidským faktorem a to jak z hlediska zákazníka, tak poskytovatele. Odvětví cestovního ruchu také vykazuje ve vysoké míře určité specifické vlastnosti služeb jako nehmatatelnost, nedělitelnost, pomíjivost a proměnlivost, které znesnadňují rozhodování zákazníka při rozhodování o výběru služby právě z důvodu složitosti posouzení kvality nabízených služeb.

Vysoká kvalita není zjistitelná vysokou cenou, přesto Hornerová a Swarbrook (2007) upozorňují, že toto vnímání je spotřebiteli více než časté. I když cena služby může být pro zákazníka významným prvkem, je pouze jen jedním ukazatelem z mnoha faktorů, které určují celkové vnímání kvality i v jednotlivých př́padech. Určující je, zda jsou naplněna očekávání zákazníka a očekávání nejsou totožná ani u různých zákazníků. Tato očekávání se mohou vyvíjet i v čase, takže nikdy zde poskytovatel nemá jistotu naprostého uspokojení zákazníka. Vysoká míra splnění očekávání zákazníka je ale pro poskytovatele důležitá nebot' vede $\mathrm{k}$ loajalitě zákazníka, jeho opakovaným nákupům, dále pak k získávání potenciálních zákazníků na základě pozitivních doporučení spokojených klientů, snižuje náklady nejen na řešení stížností, ale i na marketingové náklady v propagační oblasti.

Buhalis (2011) uvádí šest hlavních komponent destinace jako přitažlivost, dostupnost a př́stupnost služeb, komfort, nabízené turistické produkty a aktivity. Middleton a Clarke (2009) zdůrazňují image destinace, vnímání destinace a cenu. Eraqi (2006) dále zdůrazňuje komplexnost a koherentnost celého systému destinace, které je citlivé na změnu podmínek. Ryglová a kol. (2015) zdůrazňuje nejen komplexnost, ale především rozdílnost ve vnímání kvality destinace různými cílovými skupinami. Indrová a kol. (2011) chápe kvalitu služby jako vyjádření míry uspokojení požadavků zákazníka, která se skládá z těchto charakteristik: kvalita je výkon v souladu se standardem očekávání zákazníka; kvalita je uspokojení potřeb klienta - poprvé i opakovaně; kvalita znamená poskytovat zákazníkovi takové výrobky a služby, které naplňují jeho potřeby a očekávání; kvalita není jen uspokojení potřeb a očekávání zákazníka, ale navíc jejich překonání.

Ryglová, Burian, Vajčnerová (2011) chápou kvalitu v cestovním ruchu jako komplexní systém, nebot' kvalita $\mathrm{v}$ cestovním ruchu se vztahuje $\mathrm{k}$ celému řetězci na sobě závislých služeb. Obecně je s kvalitou cestovního ruchu spojeno následující:

- se zvyšující se životní úrovní se zvyšují požadavky na kvalitu služeb,

- kvalita je primárně dána kvalitou základní nabídky, odvozené nabídky a působení lidského faktoru může vnímání kvality změnit, 
- poskytovatelé služeb, kteří jsou na úrovni cestovní kanceláře nebo destinačního managementu, by měli distribuovat jen prověřené kvalitní služby,

- vymezení kvality musí být spojeno s analýzou nákladů a výnosů.

Palatková (2011) pak kvalitu destinace rozlišuje na třech úrovních. První úroveň představuje kvalita jednotlivých služeb, odděleně v jednotlivých sektorech jako např. kvalita ubytování, kvalita stravování; následuje souhrnná, agregátní kvalita služeb, např. kvalita veřejných služeb a volných statků. Ve třetí úrovni zdůrazňuje, že kvalita destinace je hodnocená nejen návštěvníky, ale i rezidenty. Bieger, Biretelli (2013) dokonce používají pojem kvalitní turismus, představující turismus v destinaci, který vede ke zvýšení kvality zážitku nejen pro návštěvníky, ale i ke zvýšení kvality života obyvatel destinace.

V souvislosti s kvalitou destinace jsou v literatuře definována i obecná hlediska, faktory, jež ovlivňují konkurenceschopnost jednotlivých poskytovatelů služeb cestovního ruchu. Maiteides, Ďad'o (2002) na základě prací Parasurmana, Zeithamlové a Berryho (1985) specifikují deset dimenzí, které by měly přispět ke kvalitě poskytovaných služeb. Kotlerovy (2007) dimenze se zaměřují také na tuto problematiku, jeho prvních pět dimenzí je orientováno na kvalitu výsledku služby, druhá polovina jím definovaných dimenzí na kvalitu procesu poskytování služby. Mezi tyto dimenze patři dostupnost - snadnost získání přístupu ke službě ve vyžadovaném čase, důvěryhodnost, znalost, spolehlivost, bezpečnost, kvalifikace, komunikace, zdvořilost, pohotovost a hmotné prvky. Hodnocení kvality definuje jako zákazníkovo porovnání toho, co očekával a toho, co se mu skutečně dostalo. Skutečné je to, co vnímá zákazník. Reálnou kvalitu tedy představuje zákazníkovo vnímání. Tento vnímaný rozdíl je i základem Parasuramanova, Zeithmalové a Berryho (1988) hodnocení kvality ve službách s použitím následující rozdílů/diferenciací, tzv. gap analýza:

- rozdíl mezi očekáváním zákazníků a způsobem, kterým jsou tato očekávání vnímána managementem organizace,

- rozdíl mezi způsobem, kterým management organizace vnímá očekávání zákazníků specifikací kvality služeb,

- rozdíl mezi specifikací kvality služeb a službami, které skutečně byly dodány,

- rozdíl mezi dodanými službami a tím, co je zákazníkům o těchto službách sdělováno a co utváŕí jejich očekávání,

- rozdíl mezi očekáváním zákazníků a jejich vnímáním skutečné kvality dodaných služeb.

Rozdíl v názorech zákazníků a poskytovatelů služeb potvrzuje řada výzkumů. Podceňování zákazníkových očekávání poskytovateli uvádí i Zorková (2016), která poukazuje na významný potenciál v oblasti zlepšování kvality turistických služeb.

\section{Výsledky a diskuze}

$\mathrm{V}$ tabulce č. 1 je uvedeno pořadí důležitosti faktorů pro hodnocení kvality destinace z pohledu poskytovatele služeb. Pořadí bylo určené na základě průměrných hodnot jednotlivých faktorů, které byly hodnoceny poskytovateli služeb. 
Tabulka 1: Pořadí významnosti faktorů kvality destinace dle poskytovatelů služeb, $n=343$

\begin{tabular}{|c|l|c|c|c|}
\hline $\begin{array}{l}\text { Č́śs } \\
\text { faktoru }\end{array}$ & Faktor & Prüměr & Medián & $\begin{array}{l}\text { Směrodatná } \\
\text { odchylka }\end{array}$ \\
\hline 14 & Pocit bezpečí & 4,50 & 5 & 0,81 \\
\hline 13 & Úroveň kvality pracovníků v službách CR & 4,46 & 5 & 0,74 \\
\hline 1 & Př́rodní atraktivity & 4,45 & 5 & 0,78 \\
\hline 2 & Kulturní památky & 4,40 & 5 & 0,78 \\
\hline 6 & Dopravní dostupnost do místa & 4,32 & 5 & 0,83 \\
\hline 11 & Image místa & 4,25 & 4 & 0,88 \\
\hline 4 & Stravování & 4,24 & 4 & 0,80 \\
\hline 15 & Čistota destinace & 4,22 & 4 & 0,87 \\
\hline 3 & Ubytovaní & 4,11 & 4 & 0,86 \\
\hline 9 & Informace a komunikace před př́ijezdem & 3,99 & 4 & 0,93 \\
\hline 10 & Přátelské př́ijetí místními obyvateli & 3,99 & 4 & 0,93 \\
\hline 8 & Dostupnost a kvalita informací & 3,93 & 4 & 0,97 \\
\hline 5 & Společenské a záźitkové akcie & 3,78 & 4 & 0,97 \\
\hline 17 & Unikátnost destinace & 3,71 & 4 & 1,04 \\
\hline 16 & Př́lidněnost destinace & 3,44 & 3 & 1,13 \\
\hline 12 & Úroveň cen služeb a zboží v destinaci & 3,43 & 3 & 1,05 \\
\hline 19 & Respektovaní udržitelného rozvoje destinace & 3,43 & 3 & 1,15 \\
\hline 18 & Doplňková infrastruktura & 3,14 & 3 & 1,23 \\
\hline 7 & Místní doprava & 3,08 & 3 & 1,22 \\
\hline
\end{tabular}

Zdroj: Vlastní zpracování.

Všechny uvedené faktory byly v bodové stupnici 1 až 5 ohodnoceny poskytovateli poměrně vysokými hodnotami. K nejvýznamnějším faktorům kvality destinace podle poskytovatelů služeb patří pocit bezpečí a úroveň kvality pracovníků ve službách cestovního ruchu. Vysoké ohodnocení lze vidět i u prŕrodních atraktivit a kulturních památek. Na druhou stranu nejméně významným faktorem z nabídnutých možností představuje pro poskytovatele služeb místní doprava následovaná doplňkovou infrastrukturou. I zde je ale míra ohodnocení nad průměrem $\mathrm{u}$ většiny respondentů, což je vidět $\mathrm{z}$ hodnoty mediánu. Nicméně s nižšś střední hodnotou dochází i ke zvyšování hodnoty směrodatné odchylky, takže názory respondentů na významnost zde nejsou tak konzistentní. Rozdílná významnost jednotlivých faktorů $\mathrm{v}$ závislosti na typu poskytovatele služby cestovního ruchu je znázorněná na Obr. 1.

Obrázek 1: Význam faktorů kvality v závislosti na typu poskytovatele služeb

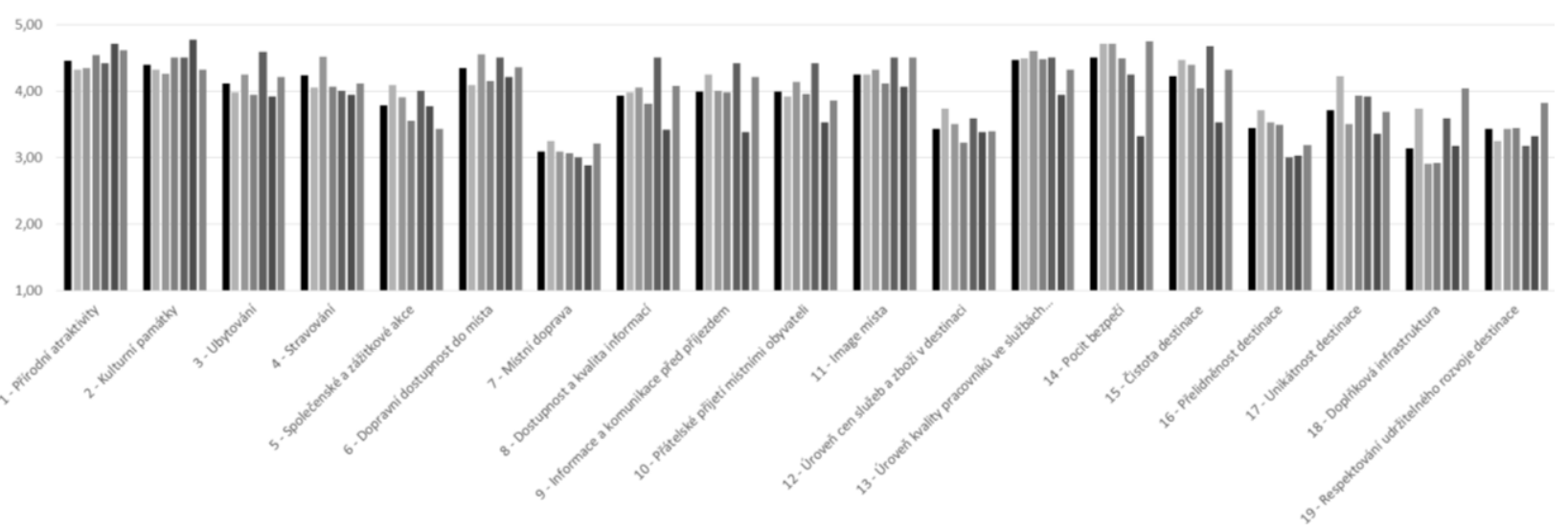




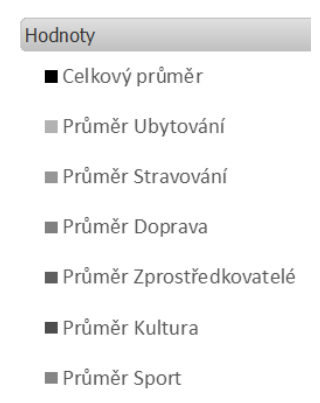

Poznámka: V bodové stupnici hodnota 1 predstavuje naprosto nevýznamný/nedůležitý faktor, hodnota 5 pak velmi významný/důležitý faktor; $n=343$

Zdroj: Vlastní zpracování.

Pokud porovnáme jednotlivé průměrné hodnoty, pak v rámci skupin poskytovatelů lze identifikovat $v$ celkovém součtu jednotlivých průměrů všech faktorů od každého poskytovatele rozdíly větší než 10 procent, kdy nejvyšší hodnotou je 4,04 a nejmenší 3,66. Souhrnně nejvýše zvolené faktory bodově hodnotí poskytovatelé nabízející ubytovací služby a zprostředkovatelé, nejméně pak pracovníci z oblasti kulturních služeb a dopravy. Při bližším pohledu je zřejmé, že vyšší hodnocení významu jednotlivých faktorů souvisí se zaměřením poskytovatele. Např. pracovníci ve stravovacích službách hodnotí vysoce mimo faktor bezpečí nejen faktor kvality stravování, ale i úroveň kvality pracovníků ve službách a dopravní dostupnost. Pro poskytovatelé ubytovacích služeb je navíc důležitý faktor týkající se informací a komunikace před př́jezdem, což souvisí s komplexnějším a časově náročnějším nákupním rozhodováním zákazníka s požadavkem na ubytování než pouze s požadavkem jednorázového stravování. Obdobně u zprostředkovatelů je faktor kvality ubytování v jejich vnímání o deset procent důležitější než faktor stravování, nebot' ubytovací služby, které jsou obvykle i doplněny stravováním, jsou pro ně primární v jejich činnosti podnikání. Navíc všechny tyto tři skupiny oproti jiným skupinám kladou vysoký důraz na čistotu destinace. Naopak poskytovatelé dopravních služeb oproti jiným poskytovatelům udávají nižší hodnoty pro tento faktor, průměrně přibližně o pět procent nižší než je celkový průměr všech poskytovatelů, který je 4,22; což je dáno zřejmě tím, že zde i jejich činností dochází ke znečištování životního prostředí. Ještě nižší hodnoty ale najdeme u poskytovatelů kulturních služeb, kdy průměrné hodnoty pro faktor čistoty destinace jsou o více než patnáct procent nižší než celkový průměr. Toto vnímání je zřejmě dáno tím, že většina významných kulturních akcí probíhá ve větších městech, kde je úklid organizován jednotlivými magistráty $\mathrm{v}$ různých časových intervalech.

Přestože dostupnost do místa je hodnocena poměrně vysoko, místní doprava není vnímána tak významně. Je to zřejmě způsobeno i poměrně dobře zabezpečenou hromadnou dopravou v České republice, takže tento faktor není vnímán jako kritický, ale také i tím, že poskytovatelé coby podnikatelé $\mathrm{z}$ důvodu zajištění vlastních služeb a s tím související přepravy prostředků pro jejich podnikání, místní dopravu nevyužívají. Poměrně zajímavý je také rozdíl v pohledu na kvalitu a dostupnost informací. Zatímco poskytovatelé ji vnímají jako velmi významnou s hodnotou 4,5; pracovníci v kultuře ji hodnotí o více než jeden bod níže, což je významný rozdíl i proti jiným skupinám poskytovatelů. Ve skutečnosti poskytovatelé kulturních služeb věnují větší úsilí a více finančních nákladů pro propagaci svých akcí, kdy podle typu zaměření využívají komerčních agentur, dotačních programů atd. Možné vysvětlení je i vaktivním působení informačních center a v současné době také neustále dostupnými informacemi prostřednictvím internetu jak na počítačích, tak ve smartphonech. Vzhledem k tomu, že poskytovatelé jsou obyvateli destinace nebo i jen působí ve svém pracovním čase $\mathrm{v}$ dané destinaci, zdůrazňují význam komunikace s návštěvníky a 
tedy i faktor přátelského přijetí místními obyvateli. Ohodnocení významu kvality tohoto faktoru je opět nižší u poskytovatelů kulturních služeb a také u poskytovatelů sportovních služeb, což souvisí s pořádáním velkých akcí ve větších městech, kde nedochází k bližšśmu kontaktu s místním obyvatelstvem. U větších akcí v menších obcích je mnohdy zaznamenán ve skutečnosti velmi negativní postoj obyvatel k organizování především hudebních festivalů z důvodu zvýšené hlučnosti či z důvodu dalšího zvýšeného znečištování životního prostředí.

Tabulka č. 2 uvádí závislost hodnocení jednotlivých faktorů na typu poskytovatele, na celkovém hodnocení kvality destinace a na činnosti destinačního managementu $\mathrm{v}$ dané destinaci.

Tabulka 2: Závislosti hodnocení faktorů kvality destinace, $n=343,5 \%$ hladina významnosti

\begin{tabular}{|c|c|c|c|c|}
\hline$\check{\mathrm{C}}$. & Faktor & $\begin{array}{c}\text { Typ } \\
\text { poskytovatele } \\
\text { služby }\end{array}$ & $\begin{array}{l}\text { Celkové } \\
\text { hodnocení } \\
\text { kvality } \\
\text { destinace }\end{array}$ & $\begin{array}{c}\text { Činnost } \\
\text { destinačního } \\
\text { managementu } \\
\text { v destinaci }\end{array}$ \\
\hline 1 & Přírodní atraktivity & Závislé & Nezávislé & Nezávislé \\
\hline 2 & Kulturní památky & Nezávislé & Závislé & Nezávislé \\
\hline 3 & Ubytování & Závislé & Nezávislé & Závislé \\
\hline 4 & Stravování & Závislé & Nezávislé & Závislé \\
\hline 5 & Společenské a zážitkové akcie & Závislé & Závislé & Nezávislé \\
\hline 6 & Dopravní dostupnost do místa & Závislé & Nezávislé & Závislé \\
\hline 7 & Místní doprava & Nezávislé & Nezávislé & Závislé \\
\hline 8 & Dostupnost a kvalita informací & Závislé & Závislé & Závislé \\
\hline 9 & Informace a komunikace před př́ijezdem & Závislé & Závislé & Nezávislé \\
\hline 10 & Přijetí místními obyvateli & Nezávislé & Závislé & Nezávislé \\
\hline 11 & Image místa & Nezávislé & Závislé & Nezávislé \\
\hline 12 & Úroveň cen služeb a zboží v destinaci & Nezávislé & Závislé & Nezávislé \\
\hline 13 & Úroveň kvality pracovníků v službách CR & Závislé & Závislé & Nezávislé \\
\hline 14 & Pocit bezpečí & Závislé & Nezávislé & Nezávislé \\
\hline 15 & Čistota destinace & Závislé & Nezávislé & Nezávislé \\
\hline 16 & Přelidněnost destinace & Závislé & Závislé & Závislé \\
\hline 17 & Unikátnost destinace & Závislé & Nezávislé & Nezávislé \\
\hline 18 & Doplňková infrastruktura & Závislé & Závislé & Nezávislé \\
\hline 19 & Respektování udržitelného rozvoje destinace & Nezávislé & Nezávislé & Nezávislé \\
\hline
\end{tabular}

Zdroj: Vlastní zpracování.

Pro testování závislosti významu faktorů ve vybraných otázkách byl použit chí-kvadrát test $\mathrm{v}$ kontingenční tabulce. Závislost na typu poskytovatele byla potvrzená na $5 \%$ hladině významnosti u 13 z 19 faktorů. Nejsilnější závislost se projevila u faktoru pocitu bezpečí, což znamená, že určitá skupina respondenti̊ nepovažuje tento faktor za tak důležitý jako jiná skupina respondentů. U zprostředkovatelů služeb cestovního ruchu se jedná až o jedenáctý nejvýznamnější faktor a u poskytovatele kulturních služeb se nachází až na patnáctém místě.

Naproti tomu je nejvíce ohodnocen poskytovateli v ubytovacích a stravovacích službách, kteří jsou v bezprostředním styku se zákazníkem. Velmi významný je také pro pracovníky v dopravě, nebot' využití dopravních prostředků představuje další potenciální rizikový faktor. Nejvíce je ale faktor pocitu bezpečí vnímán poskytovateli sportovních akcí, nejen z důvodu možných sportovních zranění, ale zejména z důvodu vyššího počtu účastníků a jejich emocionálního vypětí a to nejen u velkých a hromadných akcí. Závislost faktorů na celkovém hodnocení kvality destinace byla potvrzená na 5\% hladině významnosti u 10 z 19 faktorů. 
Vzhledem k tomu, že se jednalo o kvalitu konkrétní destinace, kde poskytovatel nabízel své služby, jsou odpovědi velmi ovlivněny subjektivním vztahem respondenta k danému místu i k jeho obyvatelům. I proto lze zřejmě nalézt nejvyšší závislost u faktoru přátelského přijetí místními obyvateli, mezi které se sám počítá. Významnou závislost lze také pozorovat u významu vnímání image místa a přelidněnosti destinace. Závislost faktorů kvality destinace na působení organizace destinačního managementu $\mathrm{v}$ dané destinaci ze strany poskytovatelů byla potvrzená na 5\% hladině významnosti u 6 z 19 faktorů. Nejvýznamněji se to týká dopravní dostupnosti do místa a místní dopravy, což je vysvětlitelné povahou poskytovaných služeb a dále také faktory kvality ubytování a stravování. U faktoru dostupnosti a kvality informací a u faktoru přelidněnosti destinace byla potvrzena ve všech př́padech závislost. Pro tři nejvíce ohodnocené faktory byla potvrzená závislost pouze na typu poskytovatele služby, závislost na celkovém hodnocení destinace a závislost na činnosti destinačního managementu nebyla potvrzená ani u jednoho z těchto faktorů.

V Tabulce č. 3. je uvedena závislost významnosti faktorů kvality destinace na převažující formě cestovního ruchu v destinaci. Byl použit Mann-Whitneyův U test na $5 \%$ hladině významnosti. Jedná se o neparametrický test, nelze předpokládat normální rozdělení pravděpodobnosti zkoumaného znaku. Testujeme nulovou hypotézu, která se týká obecných vlastností rozdělení sledované veličiny ve sledovaných souborech, tedy shodu tvaru křivky rozdělení v těchto porovnávaných souborech. Hodnocena byla rekreační, kulturně-poznávací, lázeňsko-léčebná, sportovní, kongresová a incentivní, venkovská, městská, eko a agroturistika, chataření a chalupaření, náboženská turistika, cykloturistika a nákupní turistika.

Tabulka 3: Závislost významnosti faktorů kvality destinace na převažující formě cestovního ruchu; $\mathrm{n}=343 ; 5 \%$ hladina významnosti

\begin{tabular}{|c|c|c|}
\hline $\begin{array}{l}\text { Č́slo } \\
\text { faktoru }\end{array}$ & Faktor & Převažující forma cestovního ruchu \\
\hline 1 & Př́rodní atraktivity & nebyla zjištěna závislost \\
\hline 2 & Kulturní památky & $\begin{array}{l}\text { kulturně-poznávací, kongresová a incentivní, městská, } \\
\text { chataření a chalupaření }\end{array}$ \\
\hline 3 & Ubytování & sport \\
\hline 4 & Stravování & sport, chataření a chalupaření \\
\hline 5 & Společenské a zážitkové akcie & venkovská, eko a agroturistika, chataření a \\
\hline 6 & Dopravní dostupnost do místa & $\begin{array}{l}\text { kulturně-poznávací, kongresová a incentivní, městská, } \\
\text { chataření a chalupaření, cykloturistika }\end{array}$ \\
\hline 7 & Místní doprava & rekreační, lázeňsko-léčebná \\
\hline 8 & Dostupnost a kvalita informací & rekreační, lázeňsko-léčebná \\
\hline 9 & Informace a komunikace před př́ijezdem & lázeňsko-léčebná \\
\hline 10 & Přijetí místními obyvateli & nebyla zjištěna závislost \\
\hline 11 & Image místa & $\begin{array}{l}\text { rekreační, kulturně-poznávací, kongresová a } \\
\text { incentivní, venkovská, městská, eko a agroturistika, } \\
\text { chataření a chalupaření, cykloturistika }\end{array}$ \\
\hline 12 & Úroveň cen služeb a zboží v destinaci & městská \\
\hline 13 & Úroveň kvality pracovníků v službách CR & $\begin{array}{l}\text { rekreační, kulturně-poznávací, sport, kongresová a } \\
\text { incentivní, venkovská, městská, cykloturistika }\end{array}$ \\
\hline 14 & Pocit bezpečí & nebyla zjištěna závislost \\
\hline 15 & Čistota destinace & sport \\
\hline 16 & Přelidněnost destinace & nebyla zjištěna závislost \\
\hline 17 & Unikátnost destinace & nebyla zjištěna závislost \\
\hline 18 & Doplňková infrastruktura & $\begin{array}{l}\text { rekreační, kulturně-poznávací, lázeňsko-léčebná, } \\
\text { cykloturistika, nákupní }\end{array}$ \\
\hline 19 & Respektování udržitelného rozvoje destinace & lázeňsko-léčebná, kongresová a incentivní \\
\hline
\end{tabular}

Zdroj: Vlastní zpracování. 
Nejčastěji se závislost projevila u faktoru kvality týkajícího se image místa, kde byla prokázána u všech forem mimo těch týkajících se sportu, lázní, nákupů, ale také možná překvapivě chyběla i u církevní turistiky. Žádná závislost nebyla zjištěna podle převažující formy cestovního ruchu pro faktory přírodní památky, přátelské přijetí místními obyvateli, pocit bezpečí, přelidněnost destinace a unikátnost destinace. Tam, kde v destinaci převažovala forma kulturně-poznávací, byla nejvyšší závislost dle očekávání u faktoru kvality týkajícího se kulturních památek. V souvislosti s lokací vědeckých center, univerzit a také se silně konkurenční nabídkou vědeckých konferencí byla prokázána i závislost tohoto faktoru na kongresové formě cestovního ruchu. S historickými souvislostmi koresponduje i závislost u městské turistiky. Dopravní dostupnost do místa byla zjištěna také u formy kulturněpoznávací; mnohem významnější závislost ale byla ještě vypočtena pro kongresovou a městskou turistiku, což může souviset se stále zhoršující se dopravní situací ve velkých městech z důvodu rostoucí hustoty provozu a nedostatečného počtu parkovacích míst. $\mathrm{Z}$ jiného důvodu je prokázána vysoká závislost u tohoto faktoru u cykloturistiky. I když se v současné době poskytovatelé dopravních služeb at' již v železniční nebo autobusové dopravě snaží vyjít cyklistům vstříc, zvláště pro rodiny s dětmi je tento faktor kritický. Významná závislost faktoru dopravní dostupnosti se objevila i u chataření a chalupaření, kde se může jednat o problém nedostatečně upravených cest v méně osídlených oblastech. Pro majitele či nájemníky je ale především významná doba dojezdu z bydliště k rekreačnímu zařízení. U faktoru doplňková infrastruktura se závislost nejvýznamněji projevila u lázeňskoléčebné formy cestovního ruchu, což souvisí i s jejím částečně rekreačním a relaxačním charakterem a rostoucím zájmem o zdravý a aktivní životní styl, ev. se stále atraktivnější nabídkou pro možný doprovod pacienta lázní. To se týká i nákupní turistiky, kdy je třeba najít vyplnění času pro členy rodiny s jiným než nákupním zaměřením nebo prostřídat různé aktivity v rámci např. celodenního výletu. Poněkud odlišná forma doplňkové struktury je požadována u rekreační formy a u cykloturistiky, kde byla prokázána také významná závislost.

Vysoké hodnocení významnosti jednotlivých faktorů je obdobné jako u výsledků šetření, kde byli dotazováni zákazníci služeb cestovního ruchu z roku 2015, viz Ryglová (2015). Obecně poskytovatelé služeb přiřazují ve většině případů větší význam jednotlivým faktorům kvality než klienti, hodnocení poskytovatelů služeb je v průměru vyšší o 0,3 bodu, tedy o více než pět procent. Menší význam poskytovatelé přiřazují jen faktoru úrovni cen služeb a zboží v destinaci, přelidněnosti destinace a čistotě destinace. Přitom poslední dva zmíněné faktory jsou často klíčové při rozhodování zákazníka zejména $\mathrm{v}$ oblasti well-being $\mathrm{v}$ cestovním ruchu - „Zdravého“ prožití volného času. Poptávka po tomto typu cestovního ruchu vyvolala velmi rychle př́slušnou nabídku. Mnozí noví dodavatelé služeb ale nebyli schopni nabídnout v dostatečné kvalitě požadované služby a nesplnili tak očekávání svých zákazníků. Poskytovatelé často sdružení v různých svazech a asociacích, kteří zastávají přístup nejvyšší kvality, a které i zmíněná konkurence poškozuje, se snaží nastavit standardy, které by zákazníkovi pomohli v rozhodování. Vhodným nástrojem je použití certifikátů kvality, kterou mohou poskytovatelé získat po splnění daných kritérií. Jednotlivé rozdíly ve významu faktorů kvality pro poskytovatele a klienta jsou zobrazené na Obr. 2. 
Obrázek 2: Porovnání odlišného vnímání významnosti faktorů u poskytovatelů služeb a zákazníků

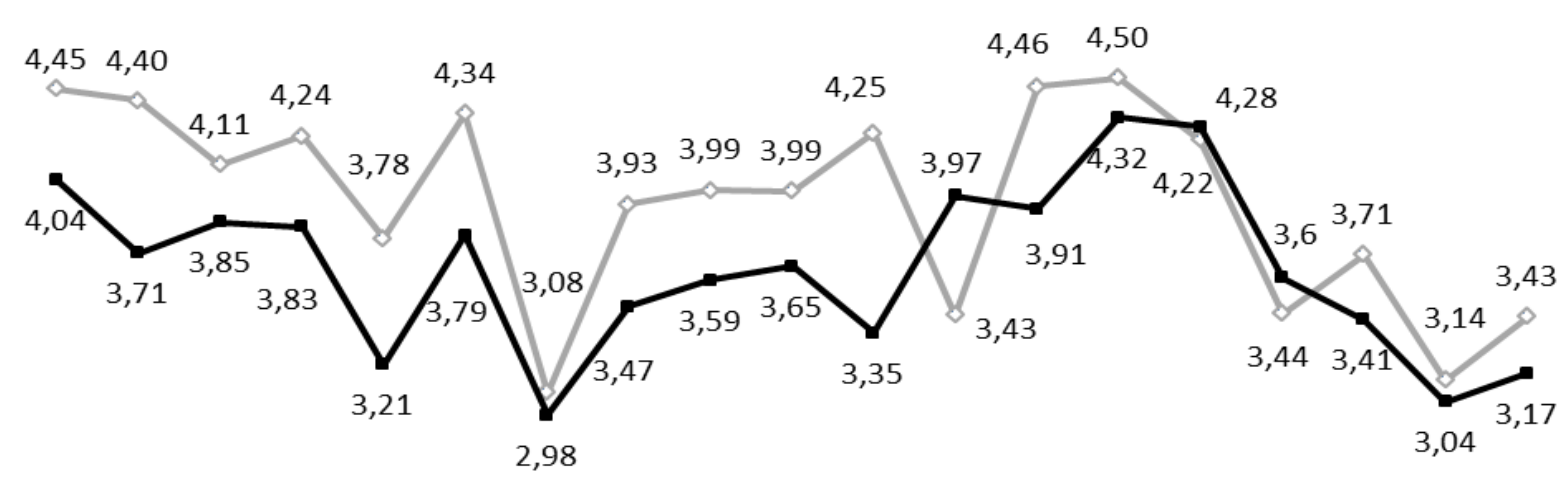

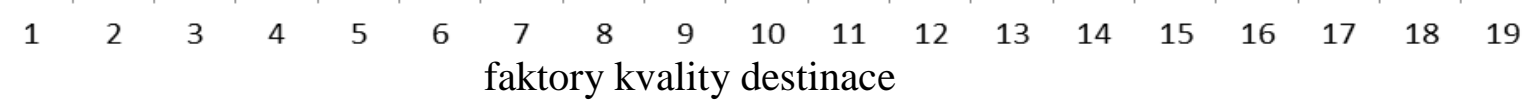

- hodnocení poskytovatelů služeb

- hodnocení zákazníků

Poznámka: Identifikace jednotlivých faktorů je uvedena v predchozích tabulkách.

Zdroj: Vlastní zpracování.

Z Obr. 2 je patrná vyšší celková významnost u většiny faktorů kvality u poskytovatelů služeb $\mathrm{v}$ cestovním ruchu. Téměř shodné průměrné hodnoty pro obě skupiny najdeme u faktoru místní dopravy a čistoty destinace, velmi podobné pak u přelidněnosti destinace a doplňkové infrastruktury. Největší pozitivní rozpor faktoru mezi poskytovatelem a klientem vzniká u faktoru image místa, kde poskytovatel hodnotí tento faktor o 0,9 bodu výše než zákazník. Tento rozdíl je možné pozorovat i při pořadí významnosti jednotlivých faktorů. Zatímco pro poskytovatele je image místa sedmým nejdůležitějším faktorem, pro klienta je to patnáctý nejdůležitější faktor. Možnou souvislost lze nalézt v tom, že poskytovatel se s místem více identifikuje, je pro něj z důvodu dlouhodobého pobytu více významnou lokalitou než pro krátkodobě se zdržujícího zákazníka. Nejvyšší negativní rozpor oproti zákazníkovi ve vnímání kvality destinaci u poskytovatele je úroveň cen služeb a zboží v destinaci. Je pravděpodobné, že v atraktivní destinaci turista počítá s vyšší hladinou cen a je ochoten se jí krátkodobě přizpůsobit, vnímá ji i jako znak kvality. Poskytovatel tento faktor hodnotí také vysoko, ale o půl bodu méně, což je rozdíl přibližně deseti procent, pravděpodobně z důvodu, že jako podnikatel má reálnější představu o nákladech a tvorbě ceny a také více vnímá svou konkurenci.

Přestože všechny faktory jsou hodnoceny poměrně vysoce, v komunikaci s potenciálním návštěvníkem destinace by měly být zohledněny zejména faktory, které zákazník vnímá jako nejvýznamnější. Jedná se především o pocit bezpečí a s ním související faktor čistoty destinace. Pro poskytovatele, který usiluje o zákazníka, at' již patří do kterékoliv skupiny poskytovatelů, by bylo vhodné vytvořit nové či doplnit současné propagační materiály o tyto aspekty a to nejen pro cílové skupiny rodičů s dětmi a seniory. Změna klasických nabídek služeb v papírové formě se provádí nicméně v delších časových intervalech a je také relativně nákladná. Nicméně v současné době lze říci, že nabídka služeb prostřednictvím 
elektronických médií je pro většinu významných cílových skupin zákazníků dostupnější než papírová forma a tedy se stává i rozhodující. Při výběru destinace potenciální návštěvníci v rámci České republiky nezadávají při hledání konkrétních služeb klíčová slova jako bezpečí a čistota, ale při prohlížení konkrétních nabídek jednotlivých služeb tyto faktory zohledňují. Designer a správce webových stránek poskytovatele služeb by tedy měli vzít v patrnost významné faktory, které určují kvalitu destinace, kde nabízí služby jeho firma. Mimo základní web stránky je ale třeba vzít v úvahu, že rozhodování o nákupu se neustále posunuje ve prospěch mobilních zařízení. Je třeba tedy zohlednit i povahu stránek zobrazujících se na smartphonech, kde je $\mathrm{k}$ dispozici rozdílná velikost plochy $\mathrm{k}$ zobrazení informací. Častým problémem reklamních sdělení poskytovatelů služeb je velké množství textu, ve kterém se významné sdělení ztratí, nebot' většinou není ani čteno. $Z$ výsledků tohoto výzkumu by tedy poskytovatel měl vybrat pro nabídku své služby to nejvýznamnější, čímž by se mohl odlišit $i$ od ostatních poskytovatelů stejných služeb. Významné faktory uvedené ve výzkumu by měl také zvýraznit i u klasických propagačních forem jako např. outdoorových reklamách, které jsou často používány u ubytovacích a stravovacích služeb a cílí na zákazníka, který se rozhoduje až v místě destinace. Pokud se střetne skutečnost s očekáváním zákazníka, pak spokojený klient se $\mathrm{k}$ osvědčenému poskytovateli opakovaně vrací a kladnými referencemi může ovlivnit k výběru destinace či konkrétní služby další potenciální návštěvníky.

Obdobně by se měly a nejen ve větších propagačních kampaních, ale v každodenní činnosti zaměřit na vnímání významnosti jednotlivých faktorů návštěvníky destinace a poskytovateli služeb také destinační společnosti. Je poněkud překvapivé, že mnoho poskytovatelů služeb neznalo nebo hodnotilo nedostatečně organizace destinačního managementu v místě svého působení. Přitom destinační společnosti mohou zvláště ve větších místech mnohem více ovlivnit vnímání kvality destinace než jednotlivý poskytovatel. Zde by bylo již vhodné intenzivnější využití např. adWords, linkbuildingu apod. Nicméně, i když je zde významnější práce s klíčovými slovy, jedná se o vytvoření pocitu z destinace, tedy o nezvolení př́mo slov jako např. bezpečí, ale vytvoření obrazového a textového materiálu, který by k tomuto pocitu vedl. I v současné době by se pak organizace destinačního managementu měly začít více zabývat širší nabídkou virtuální procházek a v budoucnu i virtuální reality, ve které by měli zohlednit výsledky tohoto výzkumu. Flexibilní koordinací činností, vytvořením systémového řešení nabídky, nabídkou kvalifikačních kurzů by také lépe uspokojily požadavky poskytovatelů $\mathrm{v}$ destinaci.

\section{Závěr}

Definované faktory určující kvalitu destinace jsou vnímány poskytovateli služeb cestovního ruchu jako významné, střední hodnoty se u všech faktorů pohybují nad průměrem z definované stupnice použité škály. Mezi nejvýznamnější faktory patří pocit bezpečí, úroveň kvality pracovníků v službách, prŕrodní atraktivity, kulturní památky a dopravní dostupnost do místa destinace. Pokud posoudíme vnímání podle typu poskytovatele, tak nejvyšší ohodnocení zvolených faktorů udávají poskytovatelé ubytovacích služby a zprostředkovatelé, nejníže pak jednotlivé faktory hodnotí pracovníci z oblasti kulturních služeb a dopravy. Závislost hodnocení faktorů kvality destinace na typu poskytovatele byla prokázána u 13 faktorů, na celkovém hodnocení kvality destinace u 10 faktorů a na činnosti destinačního managementu v dané destinaci u 6 faktorů z celkově 19 zkoumaných faktorů. Prokázaná závislost souvisí s charakterem poskytovaných služeb, které se vážou na podnikatelskou činnost poskytovatele. Závislost významnosti faktorů kvality destinace byla také testována Mann-Whitneovým U testem pro převažující formu cestovního ruchu, kde byly vybrány tyto formy cestovního ruchu - rekreační, kulturně-poznávací, lázeňsko-léčebná, sportovní, kongresová a incentivní, venkovská, městská, eko a agroturistika, chataření a chalupaření, 
náboženská turistika, cykloturistika a nákupní turistika. Závislost významnosti faktorů kvality destinace na převažující formě cestovního ruchu byla zjištěna u 14 faktorů, kdy u obecných faktorů jako např̀ pocit bezpečí nebyly nalezeny žádné rozdíly ve vnímání poskytovatelů, zatímco u specifičtějších faktorů jako např. faktoru kulturní památky byla pro poskytovatele kulturně-poznávacích služeb zjištěna významná závislost. Ve srovnání s vnímáním zákazníků je definovaných 16 z 19 faktorů kvality destinace chápáno jen jako mírně významnější u poskytovatelů služeb cestovního ruchu. Lze tedy konstatovat, že vnímání jednotlivých faktorů kvality destinace není výrazně odlišné pro obě skupiny. Určité rozdíly mohou být dány subjektivitou vnímaní faktorů kvality. Určité zkreslení při dotazování je dáno i aktuální společenskou situací, kdy respondent je ovlivněn informacemi z médií, což se v poslední době odráží na zvýšené míře citlivosti pro faktor bezpečí. Výsledky průzkumu jsou vhodné pro poskytovatele služeb, ale zejména pro pracovníky destinačního managementu, kteří na základě výše uvedených výsledků mohou upravit své cíle takovým směrem, aby došlo ke zvýšení konkurenceschopnosti destinace, kde organizace působí.

\section{Poděkování}

Tento článek vznikl za podpory grantu - GA ČR 15-21179S „The Quality Evaluation of Tourism Destination “.

\section{Literatura}

[1] BIEGER, T. and P. BERITELLI, 2013. Management von Destinationen. München: Oldenbourg. ISBN 978-3-486-71360-2.

[2] BUHALIS, D. and S. DARCY, 2011. Accessible tourism: concepts and issues. Tonawanda, NY: Channel View Publications, Aspects of tourism. ISBN 1-84541-162-5.

[3] ERAQI, M. I., 2006. Tourism services quality (TourServQual) in Egypt: The viewpoints of external and internal customers. Benchmarking: An International Journal, 13 (4), 469492. ISSN: 1463-5771.

[4] GRÖNROOS, Ch., 2007. Service management and marketing: customer management in service competition. 3rd ed. Chichester: John Wiley. ISBN 978-0-470-02862-9.

[5] GUMMESSON, E., 1993. Quality Management in Service Organizations: An Interpretation of the Service Quality Phenomenon and a Synthesis of International Research. New York: Research Report. International Service Quality Association.

[6] INDROVÁ, J., P. HOUŠKA, a Z. PETRŮ, 2011. Kvalita ve službách cestovního ruchu. Praha: Oeconomica. ISBN 978-80-245-1766-7.

[7] KOTLER, P., D. C. JAIN a S. MAESINCEE, 2007. Marketing v pohybu: nový př́stup $k$ zisku, růstu a obnově. Praha: Management Press. ISBN 978-80-7261-161-4.

[8] MATEIDES, A. a J. ĎAĎO, 2002 Služby: teória služieb, marketing služieb, kvalita v službách, služby zákazníkom a meranie spokojnosti s nimi. Bratislava: EPOS. ISBN 808057-452-9.

[9] MIDDLETON, V. T. C., A. FYALL and M. MORGAN, 2009. Marketing in travel and tourism. 4th ed. Amsterdam: Elsevier. ISBN 978-0-7506-8693-8.

[10] PALATKOVÁ, M., 2011. Mezinárodní cestovní ruch: analýza pozice turismu ve světové ekonomice, význam turismu v mezinárodních ekonomických vztazích, evropská integrace a mezinárodní turismus. Praha: Grada. ISBN 978-80-247-3750-8. 
[11] PARASURAMAN, A., V. A. ZIETHAML and L. L. BERRY, 1985. A Conceptual Model of Service Quality and Its Implications for Future Research. Journal of Marketing, 49(4), 41-50. ISSN 0022-2429.

[12] PARASURAMAN, A., V. A. ZIETHAML and L. L. BERRY, 1988. SERVQUAL: A Multiple-Item Scale for Measuring Consumer Perceptions of Service Quality. Journal of Retailing. 64(1), 12-40.

[13] PONIŠTOVÁ, N. Dimenzie kvality destinácie v cestovnom ruchu. 2017. Diplomová práce. Brno: Mendelova univerzita v Brně, Provozně ekonomická fakulta.

[14] RYGLOVÁ, K., M. BURIAN a I. VAJČNEROVÁ, 2011. Cestovní ruch - podnikatelské principy a př́ležitosti v praxi. Praha: Grada. ISBN 978-80-247-4039-3.

[15] RYGLOVÁ, K., I. VAJČNEROVÁ, J. ŠÁCHA and Š. STOJAROVÁ, 2015. The Quality as a Competitive Factor of the Destination. In Procedia Economics and Finance. 550556. DOI: $10.1016 / \mathrm{S} 2212-5671(15) 01667-6$

[16] Satelitní účet cestovního ruchu, 2017. Český statistický úřad. [online]. 27. února 2017 [vid. 10. května 2017]. Dostupné z: https://www.czso.cz/csu/czso/satelitni_ucet _cestovniho_ruchu

[17] STOJAROVÁ, Š., J. ŠÁCHA, K. RYGLOVÁ and I. VAJČNEROVÁ, 2016. The Influence of Chosen Characteristics of Social Status on Consumer's Perceptions of Destination Quality Factors. In: Book of Proceedings $9^{\text {th }}$ International Annual Conference of the EuroMed Academy of Business. pp. 1791-1797, ISBN 978-9963-711-43-7.

[18] SWARBROOKE, J. and S. HORNER, 2007. Consumer behaviour in tourism. 2. ed. Amsterdam: Butterworth-Heinemann. ISBN 0-7506-6735-4.

[19] ZORKOVÁ, D., 2016. Charakteristika poptávkové a nabídkové strany př́stupného turismu v Moravskoslezském kraji. Acta Academica Karviniensia, 16(3), 74-86. ISSN 1212-415X.

[20] WOODS, M. and J. DEEGAN, 2003. A Warm Welcome for destination quality brands: the example of the Pays Cathare region. International Journal of Tourism Research, 5 (4), 269-282. DOI: 10.1002/jtr.436 